\title{
MORPHO-AGRONOMIC CHARACTERIZATION AND GENETIC DIVERSITY IN PEPPERS (Capsicum spp.) $)^{1}$
}

\author{
MAYARA RODRIGUES E SILVA ${ }^{2}$, RAIMUNDO NONATO OLIVEIRA SILVA*
}

\begin{abstract}
Peppers and bell peppers (Capsicum spp.) are vegetables that have wide genetic variability, as well as a wide range of applications. Studies on genetic diversity help to understand the existing variability and the conservation of genetic resources, allowing breeders to select superior genotypes that meet the needs of breeding programmes. This study aimed to evaluate the genetic diversity among 15 Capsicum genotypes based on morpho-agronomic descriptors and through the Ward-MLM (Modified Location Model) procedure, as well as to indicate the most promising genotypes for breeding programmes. The research was conducted in an experimental area using a randomized block design, with three replications, using nine qualitative descriptors and ten quantitative descriptors. Analysis of variance was performed, and means were subsequently grouped by Scott-Knott's method. There was a significant difference between genotypes for all traits evaluated, making it possible to select promising genotypes. According to the Scott-Knott grouping test, the number of seeds per fruit had the largest number of groups, with eight distinct groups, while plant height had only two groups. The genotypes GEN18 and GEN21 had the highest average values for fruit wall thickness and thus are indicated for the preparation of sauces. The genotypes GEN14 and GEN16 were the most promising for use for ornamental purposes. The Ward-MLM method made it possible to differentiate $C$. annuum L., C. baccatum L., C. chinense Jacq., and C. frutescens $\mathrm{L}$. into different groups, and is thus a useful tool to detect genetic divergence.
\end{abstract}

Keywords: Pepper plants. Genetic resources. Ward-MLM. Plant breeding.

\section{CARACTERIZAÇÃO MORFOAGRONÔMICA E DIVERSIDADE GENÉTICA em pimenteiras (Capsicum spp.)}

\begin{abstract}
RESUMO - Pimentas e Pimentões (Capsicum spp.) são hortaliças que possuem ampla variabilidade genética, bem como vasta versatilidade de aplicações. Estudos sobre diversidade genética auxiliam no conhecimento da variabilidade existente e na conservação dos recursos genéticos, permitindo aos melhoristas selecionar genótipos superiores que atendam às necessidades de programas de melhoramento genético. Objetivou-se analisar a diversidade genética entre 15 genótipos de Capsicum com base em descritores agromorfológicos e por intermédio do procedimento Ward-MLM (Modified Location Model), bem como indicar os mais promissores para programas de melhoramento. A pesquisa foi conduzida em campo experimental utilizando delineamento em blocos ao acaso, com três repetições, utilizando-se nove caracteres qualitativos e 10 caracteres quantitativos. Foi utilizada análise de variância e, em seguida, as médias foram agrupadas pelo método Skott-Knott. Houve diferença significativa entre os genótipos para todas as características avaliadas, sendo possível a seleção de genótipos promissores. Considerando agrupamento Scott-Knott, a característica número de sementes por fruto obteve o maior número de grupos com oito classes distintas, enquanto a característica altura da planta formou apenas duas classes. Os genótipos GEN18 e GEN21 possuem os maiores valores médios para a caraterística espessura da parede do fruto, e podem ser indicados para o preparo de molhos. Os genótipos GEN14 e GEN16 foram os mais promissores a serem utilizados para fins ornamentais. O método de Ward-MLM possibilitou a diferenciação das espécies $C$. annuum L., C. baccatum L., C. chinense Jacq., and C. frutescens L. em grupos distintos, sendo uma ferramenta útil para detectar divergência genética.
\end{abstract}

Palavras-chave: Pimenteiras. Recursos genéticos. Ward-MLM. Melhoramento genético.

\footnotetext{
${ }^{*}$ Corresponding author

${ }^{1}$ Received for publication in 04/07/2020; accepted in 03/11/2021.

Paper of the Experimentation Research Group.

${ }^{2}$ Universidade Federal do Piauí, Floriano, PI, Brazil; mayararodrigues13@outlook.com - ORCID: 0000-0002-4281-397X, jraio@ufpi.edu.br - ORCID: 0000-0002-9987-0043.
} 


\section{INTRODUCTION}

The Capsicum genus belongs to the family Solanaceae (PICKERSGILL, 1971), and has about 38 described species, of which six are considered domesticated: $C$. annuum, $C$. assamicum, $C$. baccatum, C. chinense, $C$. frutescens and $C$. pubescens (LEE, 2019). Brazil is a vital diversity centre of the Capsicum genus, and according to Rêgo, Finger and Rêgo (2011), this existing diversity has fomented breeding programmes.

The pepper market ranges from the sale of fresh and processed fruits in the form of paprika, sauces, and preserves, to the manufacture of medicines and cosmetics (PINTO; PINTO; DONZELES, 2013). Pepper fruits have important pharmacological effects, such as anti-inflammatory and antioxidant effects (ZIMMER et al., 2012). They are also used as ornamental plants due to the aesthetic attributes they exhibit (NEITZKE et al., 2016).

In Brazil, pepper production is of great importance either because of its profitability characteristics, especially when the producer adds value to the product, or because of its social significance, by employing labour (RUFINO; PENTEADO, 2006). The growing demand of the consumer markets, both internal and external, has led to a significant increase in the area cultivated with peppers (GUERINO et al., 2017). According to Nascimento et al. (2014) there is an increasing demand for new cultivars with higher quality, yield and pest resistance, all of which can be achieved through breeding programmes.

In the municipality of Floriano - PI, there is a demand for peppers adapted to the soil and climate conditions of the region, mainly from small farmers. This emphasizes the importance of conducting work aimed at evaluating and selecting the most promising genotypes for production and marketing in the region. The Universidade Federal do Piauí, Campus Amílcar Ferreira Sobral, hosts a collection of germplasm with almost 100 genotypes; their characterization and evaluation are of fundamental importance in order to determine the genetic diversity and allow the identification of useful genotypes in improvement programmes.

Characterization of germplasm is fundamental in order to provide information for plant breeding programmes (SHEORAN et al., 2019). With the use of appropriate genetic and statistical methodologies, it is possible to assess the variability of different genotypes and their potential for use (MARIM et al., 2009).

Genetic variation can be studied through specific methods or combinations of methods, which can include the use of quantitative or qualitative characteristics (BARBÉ et al., 2010), and these characteristics can be combined using multivariate analysis techniques (FERRÃO et al., 2011). Among the multivariate methodologies, the Ward-MLM procedure proposed by Franco et al. (1998) is a technique used to assess variability using both quantitative and qualitative variables simultaneously (CAMPOS et al., 2013). This method has been applied in studies of genetic divergence, providing support for the selection of superior genotypes for breeding programmes (PESTANANA et al., 2011).

Given the above, this study aimed to evaluate the genetic diversity among 15 Capsicum genotypes based on morpho-agronomic descriptors and through the Ward-MLM procedure, as well as to identify the most promising genotypes for breeding programmes.

\section{MATERIAL AND METHODS}

The experiment was carried out in an area of the experimental farm of the Technical College of Floriano, Piauí, Brazil, latitude $6^{\circ} 45^{\prime} 45.7^{\prime \prime S}$ and longitude $43^{\circ} 03^{\prime} 31.5^{\prime \prime} \mathrm{W}$, from January to August 2016. Fifteen genotypes of Capsicum spp. (Table 1) from the Seed Collection of the Universidade Federal do Piauí, Campus Amílcar Ferreira Sobral (UFPI/CAFS), were evaluated.

Sowing was carried out in disposable $150 \mathrm{~mL}$ containers drilled at the base and filled with Plus ${ }^{\circledR}$ Garden soil. At 35 days after sowing, when the seedlings had from four to six pairs of definitive leaves, they were transplanted into the experimental field. Transplants were placed in holes, using a spacing of $1.0 \mathrm{~m}$ between rows and $0.50 \mathrm{~m}$ between plants. The experimental design used was a randomized block with three replications and four plants per plot, the useful plot consisting of the two central plants. Mineral fertilizer (NPK - 5:30:15) and goat manure were applied in each planting hole. A drip irrigation system was used, and crop management was carried out according to the recommendations for the crop (FILGUEIRA, 2008).

The characterization of the genotypes was based on a list of ten quantitative and nine qualitative descriptors suggested by the International Plant Genetic Resources Institute (IPGRI, 1995). The following quantitative descriptors were evaluated: mature leaf length (LFL - mm), mature leaf width (LFW $-\mathrm{mm})$, stem diameter (SDM - mm), plant height $(\mathrm{PHT}-\mathrm{cm})$, days to flowering (DTF - days), fruit pedicel length (FPL $-\mathrm{mm}$ ), fruit length (FLT $\mathrm{mm}$ ), fruit width (FWL $-\mathrm{mm}$ ), number of seeds per fruit (NSF) and fruit wall thickness (FWT $-\mathrm{mm}$ ). Measurements of plant height and stem diameter were made with the aid of a tape measure graduated in centimetres. The leaf and fruit measurements were made with the aid of a digital caliper (Pantec $\mathbb{R}$ digital caliper) graduated in millimetres, measuring five leaves and five fruits per plant. 
Table 1. Identification and origin of 15 pepper genotypes from the Seed Collection of the Universidade Federal do Piauí, Campus Amílcar Ferreira Sobral (UFPI/CAFS).

\begin{tabular}{lccc}
\hline Genotype & Identification & Popular name & Source \\
\hline GEN02 & Capsicum baccatum & Pimenta dedo de moça & Brasília-DF \\
GEN05 & Capsicum frutescens & Pimenta Malagueta & Natal-RN \\
GEN06 & Capsicum frutescens & Pimenta Malagueta & União-PI \\
GEN09 & Capsicum baccatum & Pimenta dedo de moça & Teresina-PI \\
GEN10 & Capsicum chinense & Pimenta de Cheiro & Teresina-PI \\
GEN12 & Capsicum chinense & Pimenta Murici & Teresina-PI \\
GEN14 & Capsicum annuum & Pimenta Ornamental & Teresina-PI \\
GEN15 & Capsicum frutescens & Pimenta Malagueta & Teresina-PI \\
GEN16 & Capsicum annuum & Pimenta Ornamental & Teresina-PI \\
GEN17 & Capsicum chinense & Pimenta Bode & Brasília-DF \\
GEN18 & Capsicum annuum & Pimentão & Ribeirão Preto-SP \\
GEN21 & Capsicum annuum & Pimentão & Ribeirão Preto-SP \\
GEN26 & Capsicum frutescens & Pimenta Malagueta & Floriano-PI \\
GEN28 & Capsicum annuum & Pimentão Magna Super & Floriano-PI \\
GEN30 & Capsicum annuum & Pimentão Amarelo Sf* 134 & Floriano-PI \\
\hline
\end{tabular}

*Sf - Self-fertilization.

The following qualitative descriptors were also evaluated: stem colour (STC), leaf shape (LFS), number of flowers per axil (NFA), flower position (FPS), corolla colour (CCL), corolla spot colour (CSC), anther colour (ACL), fruit colour at intermediate stage $(\mathrm{FCI})$, and fruit colour at mature stage (FCM).

The data were subjected to analysis of variance, and the Scott-Knott test grouped the means at $5 \%$ probability. The joint analysis of the quantitative and qualitative characters was performed using the Ward-MLM method, proposed by Franco et al. (1998), using the Gower dissimilarity matrix. The ideal number of groups was defined based on the likelihood function criterion, maximized according to the MLM method, and differences between them were analysed using canonical variables. Analysis of variance and Scott Knott grouping were performed using the Genes program (CRUZ, 2013). The quantitative and qualitative variables were analysed simultaneously based on the Ward-MLM method using SAS program version 9.0 (SAS Institute, Cary, North Carolina, USA). Figures were made using the SigmaPlot ${ }^{\circledR}$ software (version 10.0).

\section{RESULTS AND DISCUSSION}

There was a significant difference $(p<0.01)$ among the genotypes for all characters evaluated (Table 2), demonstrating the existence of genetic variability, and thus making it possible to select superior individuals. It is worth mentioning that, according to Cruz, Carneiro and Regazzi (2014), the existence of genetic variability in a population is a determining factor for success in any breeding programme.

The values of the coefficients of experimental variation $(\mathrm{CVs})$ ranged between $6.80 \%$ (DTF) and $25.18 \%$ (SDM). According to Pimentel-Gomes (1990), most CVs were considered low (below 10\%) and moderate (from 10 to $20 \%$ ), except for SDM, PHT and FWL. This classification (from low to moderate) for most of the characters evaluated demonstrates little influence of the environment, conferring credibility to the results obtained and indicating good experimental precision. In a study of peppers, Silva et al. (2011) determined that the CV varied according to trait, genotype and species under study. 
M. R. SILVA; R. N. O. SILVA

Table 2. Mean squares and coefficient of variation (CV) obtained in the analysis of variance of ten characters evaluated in 15 pepper genotypes from the Seed Collection of the Universidade Federal do Piauí, Campus Amílcar Ferreira Sobral (UFPI/CAFS).

\begin{tabular}{ccccccc}
\hline & & \multicolumn{5}{c}{ Mean square } \\
\cline { 3 - 6 } SV & DF & LFL & MLW & SDM & PHT & DTF \\
\hline Replication & 2 & 38.84 & 35.57 & 15.59 & 65.69 & 4.29 \\
Genotypes & 14 & $349.9^{* *}$ & $183.56^{* *}$ & $20.01^{* *}$ & $401.26^{* *}$ & $118.04^{* *}$ \\
Error & 28 & 33.81 & 6.87 & 6.25 & 88.78 & 10.07 \\
\hline Mean & & 64.24 & 29.85 & 9.93 & 44.58 & 46.71 \\
CV (\%) & & 9.05 & 8.78 & 25.18 & 21.14 & 6.80 \\
\hline & & & & & FWT \\
\hline SV & DF & FPL & FLT & FWL & NSF & 0.01 \\
\hline Replication & 2 & 2.18 & 33.28 & 28.06 & 2.37 & $3.94 * *$ \\
Genotypes & 14 & $98.46^{* *}$ & $1229.83^{* *}$ & $624.99 * *$ & $1605.09 * *$ & 0.07 \\
Error & 28 & 10.75 & 41.29 & 19.40 & 18.23 & 2.02 \\
\hline Mean & & 26.98 & 37.16 & 19.48 & 28.4 & 13.53 \\
CV (\%) & & 12.15 & 17.29 & 22.62 & 15.04 &
\end{tabular}

**Significant at $1 \%$ probability by the $\mathrm{F}$ test.

SV: source of variation; DF: degrees of freedom; Characteristics: mature leaf length (LFL), mature leaf width (MLW), stem diameter (SDM), plant height (PHT), days to flowering (DTF), fruit pedicel length (FPL), fruit length (FLT), fruit width (FWL), number of seeds per fruit (NSF), and fruit wall thickness (FWT).

Regarding the average values grouped by the Scott-Knott test, the genotypes for NSF were grouped into eight distinct groups (Table 3), demonstrating the high variability of genotypes for this characteristic. Rufino and Penteado (2006) affirmed that the NSF characteristic is relevant for commercialization, given that the farmer can obtain profits if they choose to sell the seeds.

The LFL, SDM, DTF and FLP formed three distinct groups, while for MLW four distinct groups were observed (Table 3), demonstrating the variability of these traits. The highest mean values for length were observed for genotypes GEN06, GEN15, GEN18 and GEN21 (Table 3), while for leaf width the genotype GEN02 had the highest mean value. According to Taiz and Zeiger (2013) leaf length and width are very important characteristics, given the direct relationship between leaf area, photosynthesis and plant growth and development. The genotypes GEN14 and GEN16 had the lowest average values in terms of leaf length and width. These characters are relevant due to their ornamental traits, with Barroso et al. (2012) affirming that pepper genotypes with smaller leaves are interesting for this purpose.

The characteristic with the lowest number of groups was PHT (with two distinct groups), indicating greater uniformity among individuals for this attribute. The genotypes GEN16 and GEN14 had the lowest averages for PHT, at $20.33 \mathrm{~mm}$ and 23.33 $\mathrm{mm}$, respectively. According to Costa et al. (2019), smaller pepper genotypes (heights of 6 to $32 \mathrm{~cm}$ ) are ideal for growing in pots, while larger ones can be grown in gardens.

For FLT the genotypes GEN09, GEN10 and GEN18 stood out, while GEN18 and GEN21 stood out for the FWT (Table 3). In the species C. annuum the GEN18 genotype stood out for both FLT (63.34 $\mathrm{mm}$ ) and FWL (46.81 $\mathrm{mm})$, with the highest average values for both characters (Table 3 ). These attributes indicate that this genotype is promising for fresh use and the production of sauces. The length and width of the fruit are essential attributes for commercialization, since according to Blat, Braz and Arruda (2007) the trade values large fruits. The highest average values for fruit wall thickness were observed in genotypes GEN18, GEN21, GEN28, and GEN30. These genotypes are promising as important gene sources for breeding programmes since, according to Charlo et al. (2009), fruits that have thicker walls are more resistant to transport, have a longer postharvest duration, and a greater mass yield, besides being preferred by the market. 
Table 3. Means of ten quantitative descriptors referring to 15 pepper genotypes from the Seed Collection of the Universidade Federal do Piauí, Campus Amílcar Ferreira Sobral (UFPI/CAFS).

\begin{tabular}{ccccccccccc}
\hline Genotype & $\begin{array}{c}\text { LFL } \\
(\mathrm{mm})\end{array}$ & $\begin{array}{c}\text { MLW } \\
(\mathrm{mm})\end{array}$ & $\begin{array}{c}\text { SDM } \\
(\mathrm{mm})\end{array}$ & $\begin{array}{c}\text { PHT } \\
(\mathrm{cm})\end{array}$ & $\begin{array}{c}\text { DTF } \\
(\text { days })\end{array}$ & $\begin{array}{c}\text { FPL } \\
(\mathrm{mm})\end{array}$ & $\begin{array}{c}\text { FLT } \\
(\mathrm{mm})\end{array}$ & $\begin{array}{c}\text { FWL } \\
(\mathrm{mm})\end{array}$ & NSF & $\begin{array}{c}\text { FWT } \\
(\mathrm{mm})\end{array}$ \\
\hline GEN02 & $67.36 \mathrm{~b}$ & $43.09 \mathrm{a}$ & $6.78 \mathrm{c}$ & $33.66 \mathrm{~b}$ & $49.66 \mathrm{~b}$ & $34.84 \mathrm{a}$ & $47.30 \mathrm{~b}$ & $16.65 \mathrm{c}$ & $73.29 \mathrm{~b}$ & $1.60 \mathrm{c}$ \\
GEN05 & $68.40 \mathrm{~b}$ & $27.02 \mathrm{c}$ & $9.83 \mathrm{c}$ & $49.00 \mathrm{a}$ & $49.33 \mathrm{~b}$ & $22.89 \mathrm{c}$ & $20.62 \mathrm{~d}$ & $4.17 \mathrm{~d}$ & $16.14 \mathrm{~g}$ & $0.60 \mathrm{~d}$ \\
GEN06 & $78.37 \mathrm{a}$ & $32.49 \mathrm{~b}$ & $11.16 \mathrm{~b}$ & $46.00 \mathrm{a}$ & $48.66 \mathrm{~b}$ & $24.50 \mathrm{c}$ & $17.94 \mathrm{~d}$ & $4.10 \mathrm{~d}$ & $13.11 \mathrm{~g}$ & $0.45 \mathrm{~d}$ \\
GEN09 & $65.61 \mathrm{~b}$ & $34.40 \mathrm{~b}$ & $11.64 \mathrm{~b}$ & $52.00 \mathrm{a}$ & $44.00 \mathrm{c}$ & $38.45 \mathrm{a}$ & $73.10 \mathrm{a}$ & $20.01 \mathrm{c}$ & $42.95 \mathrm{c}$ & $2.13 \mathrm{~b}$ \\
GEN10 & $62.85 \mathrm{~b}$ & $36.38 \mathrm{~b}$ & $8.75 \mathrm{c}$ & $39.33 \mathrm{a}$ & $56.66 \mathrm{a}$ & $27.72 \mathrm{~b}$ & $63.41 \mathrm{a}$ & $12.39 \mathrm{c}$ & $14.18 \mathrm{~g}$ & $1.75 \mathrm{c}$ \\
GEN12 & $59.52 \mathrm{~b}$ & $27.94 \mathrm{c}$ & $6.35 \mathrm{c}$ & $49.66 \mathrm{a}$ & $55.00 \mathrm{a}$ & $21.15 \mathrm{c}$ & $18.22 \mathrm{~d}$ & $16.70 \mathrm{c}$ & $23.05 \mathrm{f}$ & $1.69 \mathrm{c}$ \\
GEN14 & $46.34 \mathrm{c}$ & $14.73 \mathrm{~d}$ & $8.13 \mathrm{c}$ & $23.33 \mathrm{~b}$ & $40.33 \mathrm{c}$ & $25.68 \mathrm{c}$ & $27.99 \mathrm{c}$ & $19.36 \mathrm{c}$ & $26.42 \mathrm{e}$ & $2.31 \mathrm{~b}$ \\
GEN15 & $72.41 \mathrm{a}$ & $34.53 \mathrm{~b}$ & $11.68 \mathrm{~b}$ & $55.33 \mathrm{a}$ & $48.66 \mathrm{~b}$ & $23.32 \mathrm{c}$ & $16.47 \mathrm{~d}$ & $4.10 \mathrm{~d}$ & $6.64 \mathrm{~h}$ & $0.68 \mathrm{~d}$ \\
GEN16 & $40.65 \mathrm{c}$ & $13.96 \mathrm{~d}$ & $9.48 \mathrm{c}$ & $20.33 \mathrm{~b}$ & $39.66 \mathrm{c}$ & $28.63 \mathrm{~b}$ & $30.96 \mathrm{c}$ & $20.52 \mathrm{c}$ & $27.31 \mathrm{e}$ & $2.11 \mathrm{~b}$ \\
GEN17 & $57.51 \mathrm{~b}$ & $36.12 \mathrm{~b}$ & $7.27 \mathrm{c}$ & $44.66 \mathrm{a}$ & $56.66 \mathrm{a}$ & $18.98 \mathrm{c}$ & $12.88 \mathrm{~d}$ & $14.54 \mathrm{c}$ & $35.15 \mathrm{~d}$ & $2.18 \mathrm{~b}$ \\
GEN18 & $82.04 \mathrm{a}$ & $35.92 \mathrm{~b}$ & $9.77 \mathrm{c}$ & $46.66 \mathrm{a}$ & $41.33 \mathrm{c}$ & $28.60 \mathrm{~b}$ & $63.34 \mathrm{a}$ & $46.81 \mathrm{a}$ & $86.06 \mathrm{a}$ & $3.55 \mathrm{a}$ \\
GEN21 & $70.89 \mathrm{a}$ & $27.70 \mathrm{c}$ & $9.14 \mathrm{c}$ & $51.00 \mathrm{a}$ & $44.33 \mathrm{c}$ & $19.28 \mathrm{c}$ & $38.76 \mathrm{c}$ & $46.95 \mathrm{a}$ & $18.33 \mathrm{f}$ & $3.68 \mathrm{a}$ \\
GEN26 & $67.69 \mathrm{~b}$ & $27.07 \mathrm{c}$ & $16.51 \mathrm{a}$ & $56.66 \mathrm{a}$ & $48.66 \mathrm{~b}$ & $25.71 \mathrm{c}$ & $19.71 \mathrm{~d}$ & $4.77 \mathrm{~d}$ & $6.72 \mathrm{~h}$ & $0.54 \mathrm{~d}$ \\
GEN28 & $59.99 \mathrm{~b}$ & $27.14 \mathrm{c}$ & $12.63 \mathrm{~b}$ & $40.33 \mathrm{a}$ & $38.33 \mathrm{c}$ & $33.66 \mathrm{a}$ & $53.47 \mathrm{~b}$ & $21.69 \mathrm{c}$ & $21.58 \mathrm{f}$ & $3.40 \mathrm{a}$ \\
GEN30 & $63.86 \mathrm{~b}$ & $29.14 \mathrm{~b}$ & $9.73 \mathrm{c}$ & $60.66 \mathrm{a}$ & $39.33 \mathrm{c}$ & $31.31 \mathrm{~b}$ & $53.14 \mathrm{~b}$ & $39.34 \mathrm{~b}$ & $14.94 \mathrm{~g}$ & $3.58 \mathrm{a}$ \\
\hline
\end{tabular}

Means followed by the same letter, in each column, belong to the same group, according to the Scott-Knott test ( $p \leq 0.05)$. Descriptors: Mature leaf length (LFL), mature leaf width (MLW), stem diameter (SDM), plant height (PHT), days to flowering (DTF), fruit pedicel length (FPL), fruit length (FLT), fruit width (FWL), number of seeds per fruit (NSF), and fruit wall thickness (FWT) of 15 pepper genotypes.

The Log-Likelihood function showed that the optimal number of groups was four, with a maximum increase of $41.47 \%$, according to the pseudo-F and pseudo-t2 statistics score, as obtained using the Ward-MLM strategy (Figure 1).

The first two canonical variables obtained by the Ward-MLM method explained $99.73 \%$ of the total variation (Figure 2), illustrating the genetic variability between the genotypes evaluated by dispersion graphical analysis. Ferrão et al. (2011) also used canonical variable techniques in research on genetic divergence among pepper genotypes involving dispersion graphs, demonstrating efficiency in the separation of the genotypes. According to Cruz, Carneiro and Regazzi (2014), when values exceed $80 \%$ of the total variation for the first two canonical variables, a satisfactory description of the variability between the genotypes is possible, allowing their representation in a twodimensional scatter plot.

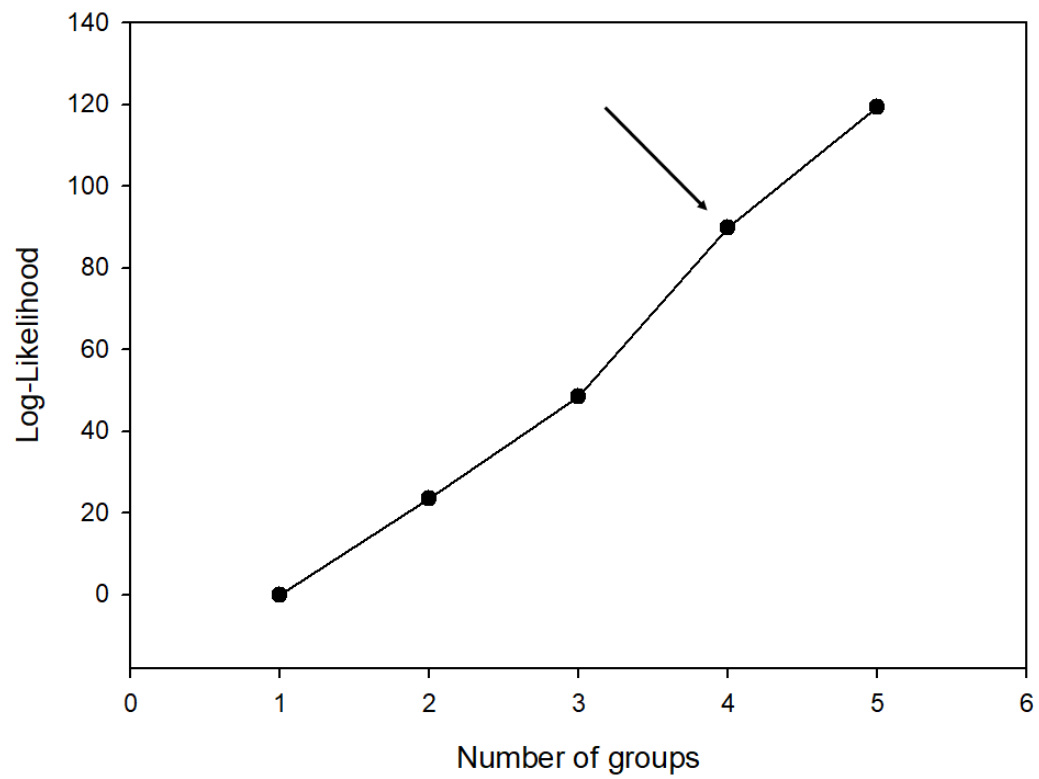

Figure 1. Graph of the logarithmic likelihood function (Log-Likelihood) showing the optimum number of groups formed using the Ward MLM strategy in pepper genotypes. 
The joint analysis of the quantitative and qualitative characters yielded four groups (Figure 1). Group I consisted of genotypes GEN05, GEN06, GEN15, and GEN26, which belong to the species $C$. frutescens. The individuals in this group have floral structures with a yellow and greenish-yellow colour, with two flowers per axil, lanceolate leaves and redcoloured fruits at the final stage of maturation (Table
4). The genotypes GEN05, GEN15 and GEN26 are characterized by the presence of erect flowers. The genotypes of this group, represented by chilli peppers, have the lowest average values for the characteristics of fruit width, fruit length, and fruit wall thickness. According to Bento et al. (2007), chilli pepper fruits have greater potential to be marketed for the production of industrialized sauces.

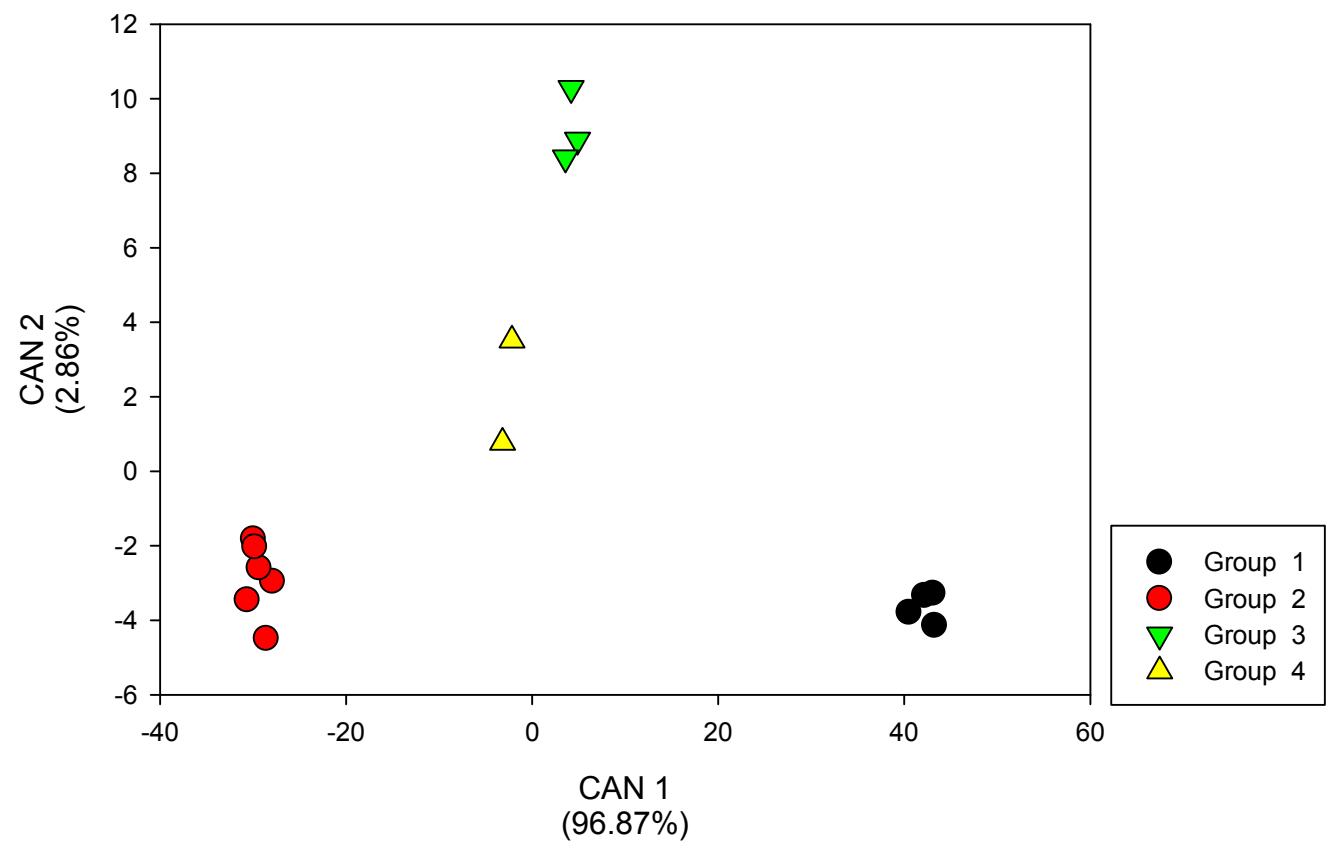

Figure 2. Graphic dispersion for the first two canonical variables (CAN 1 and CAN 2) representing the formation of four groups using the Ward-MLM method for the quantitative and qualitative characteristics in Capsicum spp. Group 1: Capsicum frutescens; Group 2: Capsicum annuum; Group 3: Capsicum chinense, and Group 4: Capsicum baccatum.

Group II consisted of the genotypes GEN14, GEN16, GEN18, GEN21, GEN28, and GEN30, belonging to the species $C$. annuum. This group includes the genotypes with the lowest average values for the DTF characteristic (Table 3). Genotypes with these attributes are of interest for breeding programmes since precocity is a characteristic of great importance for the development of superior genotypes and should be explored.

The fruits of the genotypes GEN14, GEN18, and GEN28, when ripe, are red (Table 4). According to Lannes et al. (2007), red-coloured fruit is one of the desired attributes for use as paprika. The individuals GEN16, GEN21, and GEN30 produce orange fruits, being quite attractive for ornamental purposes. It is worth mentioning that, according to Neitzke et al. (2016), the colour of the fruits is the most relevant factor when purchasing ornamental peppers.

The genotypes GEN02, GEN14 and GEN16 had the lowest averages for plant height (Table 3).
Belonging to the species $C$. annuum, the genotypes GEN14 and GEN16 therefore have potential for ornamental purposes, since according to Costa et al. (2019), plants with smaller heights are more suitable for cultivation in pots. The genotypes GEN18 and GEN21 had the highest mean values for fruit wall thickness. This is attractive for the commercialization of fresh fruit or to produce sauces. According to Blat, Braz and Arruda (2007), the thickness of the fruit wall is linked to fruit quality and yield. Thicker fruits are more resistant to damage during transport, besides being used in sauce production.

Group III is represented by $C$. chinense genotypes: GEN10, GEN12, and GEN 17. These have two flowers per axil, which are erect and pendant, with oval-shaped leaves. Fruit colour at the intermediate stage is orange and yellow (Table 4). The fruits varied in length and width, demonstrating intraspecific diversity. 
Table 4. Variables and number of genotypes per group of qualitative characteristics, in each of the four groups (G1, G2, G3, and G4) formed using the Ward-MLM strategy in 15 pepper genotypes from the Seed Collection of the Universidade Federal do Piauí, Campus Amílcar Ferreira Sobral (UFPI/CAFS).

\begin{tabular}{|c|c|c|c|c|}
\hline \multirow{2}{*}{ Variables } & \multicolumn{4}{|c|}{ Groups } \\
\hline & G1(04) & G2(06) & G3(03) & $\mathrm{G} 4(02)$ \\
\hline \multicolumn{5}{|l|}{ Stem colour (STC) } \\
\hline Green & 1 & 5 & 1 & 1 \\
\hline Green with purple stripes & 3 & 1 & 2 & 1 \\
\hline \multicolumn{5}{|l|}{ Leaf shape (LFS) } \\
\hline Deltoid & - & - & - & 2 \\
\hline Ovate & - & - & 3 & - \\
\hline Lanceolate & 4 & 6 & - & - \\
\hline \multicolumn{5}{|c|}{ Number of flowers per axil (NFA) } \\
\hline One & - & 6 & - & 2 \\
\hline Two & 4 & - & 3 & - \\
\hline \multicolumn{5}{|l|}{ Flower position (FPS) } \\
\hline Pendant & - & 2 & 2 & - \\
\hline Intermediate & 1 & - & - & 2 \\
\hline Erect & 3 & 4 & 1 & - \\
\hline \multicolumn{5}{|l|}{ Corolla colour (CCL) } \\
\hline White & - & 6 & - & 2 \\
\hline Light-yellow & - & - & 1 & - \\
\hline Yellow & 1 & - & 1 & - \\
\hline Yellow-green & 3 & - & 1 & - \\
\hline \multicolumn{5}{|l|}{ Corolla spot colour (CSC) } \\
\hline White & 2 & 6 & 3 & - \\
\hline Yellow & - & - & - & 2 \\
\hline Green-yellow & 2 & - & - & - \\
\hline \multicolumn{5}{|l|}{ Anther colour (ACL) } \\
\hline White & - & - & 1 & - \\
\hline Yellow & - & 1 & - & 2 \\
\hline Blue & 1 & - & - & - \\
\hline Purple & 3 & 5 & 2 & - \\
\hline \multicolumn{5}{|c|}{ Fruit colour at intermediate stage (FCI) } \\
\hline Yellow & - & 1 & 2 & - \\
\hline Green & - & 3 & - & - \\
\hline Orange & 3 & - & 1 & 2 \\
\hline Purple & 1 & 2 & - & - \\
\hline \multicolumn{5}{|c|}{ Fruit colour at mature stage (FCM) } \\
\hline Orange & - & 3 & 2 & - \\
\hline Red & 4 & 3 & 1 & 2 \\
\hline
\end{tabular}

Group IV comprised the genotypes GEN02 and GEN09, belonging to the species C. baccatum. These genotypes have a white corolla with yellow spots and anthers. According to Vasconcelos et al. (2012), flower characters can be used as morphological markers to determine genetic diversity and discriminate species. Fruits at the intermediate stage are orange, while in the final maturation stage they are red.

High genetic variability is essential for germplasm collections when we consider the source of alleles present in those plant genetic resources. According to Moreira et al. (2018) the preservation of such resources is of extreme importance for plant breeding, as well as for society as a whole.

\section{CONCLUSIONS}

There is genetic diversity among the studied 
genotypes.

The Ward-MLM strategy was very useful to detect genetic divergence and to cluster the genotypes by species.

The genotypes GEN18 and GEN21 are indicated for fresh consumption and processing in the form of sauces and paprika.

GEN14 and GEN16 can be used as ornamental peppers.

GEN14, GEN16, GEN18, GEN21 and GEN30 genotypes can be used in genetic breeding programmes.

\section{REFERENCES}

BARBÉ, T. C. et al. Association between advanced generations and genealogy in inbred lines of snap bean by the Ward-Modified Location Model. Euphytica, 173: 337-343, 2010.

BARROSO, P. A. et al. Analysis of segregating generation for components of seedling and plant height of pepper (Capsicum annuum L.) for medicinal and ornamental purposes. Acta Horticulturae, 953: 269-275, 2012.

BENTO, C. S. et al. Descritores qualitativos e multicategóricos na estimativa da variabilidade fenotípica entre acessos de pimentas. Scientia Agraria, 8: 149-157, 2007.

BLAT, S. F.; BRAZ, L. T.; ARRUDA, A. D. S. Avaliação de híbridos duplos de pimentão. Horticultura Brasileira, 25: 350-354, 2007.

CAMPOS, B. M. et al. Quantificação da divergência genética entre acessos de goiabeira por meio da estratégia Ward-MLM. Revista Brasileira de Fruticultura, 35: 571-578, 2013.

CHARLO, H. C. D. O. et al. Cultivo de híbridos de pimentão amarelo em fibra da casca de coco. Horticultura Brasileira, 27: 155-159, 2009.

COSTA, G. N. et al. Selection of pepper accessions with ornamental potential. Revista Caatinga, 32: 566-574, 2019.

CRUZ, C. D. Genes: A software package for analysis in experimental statistics and quantitative genetics. Acta Scientiarum. Agronomy, 35: 271276, 2013.

CRUZ, C. D.; CARNEIRO, P. C. S.; REGAZZI, A. J. Modelos biométricos aplicados ao melhoramento genético. 3 ed. Viçosa, MG: UFV, 2014. 508 p.

FERRÃO, F. V. et al. Divergência genética entre genótipos de pimenta com base em caracteres morfoagrônomicos. Horticultura Brasileira, 29: 354-358, 2011.

FILGUEIRA, F. A. R. Novo manual de olericultura: agrotecnologia moderna na produção e comercialização de hortaliças. Viçosa, MG: UFV, 2008. 421 p.

FRANCO, J. et al. Classifying genetic resources by categorical and continuous variables. Crop Science, 38: 1688-1696, 1998

GUERINO, R. S. et al. Productive viability of sweet pepper (Capsicum chinense [J.] cv. Lupita) using water management with different soil water tensions. Australian Journal of Crop Science, 11: 16511656, 2017.

IPGRI - International Plant Genetic Resources Institute. Descriptors for Capsicum - (Capsicum spp.). Rome, 1995. 51 p.

LANNES, S. D. et al. Growth and quality of Brazilian accessions of Capsicum chinense fruits. Scientia Horticulturae, 112: 266-270, 2007.

LEE, J. Development and Evolution of Molecular Markers and Genetic Maps in Capsicum Species. In: RAMCHIARY, N.; KOLE, C. (Eds.). The Capsicum Genome. Cham, Switzerland: Springer Nature Switzerland, 2019. v. 1, cap. 5, p. 85-103.

MARIM, B. G. et al. Variabilidade genética e importância relativa de caracteres em acessos de germoplasma de tomateiro. Pesquisa Agropecuária Brasileira, 44: 1283-1290, 2009.

MOREIRA, A. F. P. et al. Genetic diversity, population structure and genetic parameters of fruit traits in Capsicum chinense. Scientia Horticulturae, 236: 1-9, 2018

NASCIMENTO N. F. F. et al. Combining ability for yield and fruit quality in the pepper Capsicum annuиm. Genetics and Molecular Research, 13: 3237-3249, 2014.

NEITZKE, R. S. et al. Pimentas ornamentais: aceitação e preferências do mercado consumidor. Horticultura Brasileira, 34: 102-109, 2016.

PESTANANA, R. K. N. et al. Agronomic and molecular characterization of gamma ray induced banana (Musa sp.) mutants using a multivariate statistical algorithm. Euphytica, 178: 151-158, 2011 .

PICKERSGILL, B. Relationship between weedy and cultivated forms in some species of chilli peppers 
(Genus Capsicum). Evolution, 25: 683-691, 1971.

PIMENTEL-GOMES, F. Curso de estatística experimental. 13 ed. Piracicaba, SP: Nobel, 1990. 468 p.

PINTO, C. M. F.; PINTO, C. L. O.; DONZELES, S. M. L. Pimenta Capsicum: propriedades químicas, nutricionais, farmacológicas e medicinais e seu potencial para o agronegócio. Revista Brasileira de Agropecuária Sustentável, 3: 108-120, 2013.

RÊGO, E. R.; FINGER, L. F.; RÊGO, M. M. Produção, genética e melhoramento de pimentas (Capsicum spp.). 1. ed. Recife, PE: Imprima, 2011. $223 \mathrm{p}$.

RUFINO, J. L. S.; PENTEADO, D. C. S. Importância econômica, perspectivas $\mathrm{e}$ potencialidades do mercado para pimenta. Informe Agropecuário, 27: 7-15, 2006.

SHEORAN, S. et al. Uncovering genomic regions associated with 36 agro-morphological traits in Indian spring wheat using GWAS. Frontiers in Plant Science, 10: 1-20, 2019.

SILVA, A. R. et al. Avaliação do coeficiente de variação experimental para caracteres de frutos de pimenteiras. Revista Ceres, 58: 168-171, 2011.

TAIZ, L.; ZEIGER, E. Fisiologia vegetal. 5. ed. Porto Alegre, RS: Artmed, 2013. 918 p.

VASCONCELOS, C. S. et al. Determinação da dissimilaridade genética entre acessos de Capsicum chinense com base em característica de flores. Revista Ceres, 59: 493-498, 2012.

ZIMMER, A. R. et al. Antioxidant and antiinflammatory properties of Capsicum baccatum: from traditional use to scientific approach. Journal of Ethnopharmacology, 139: 228-233, 2012. 